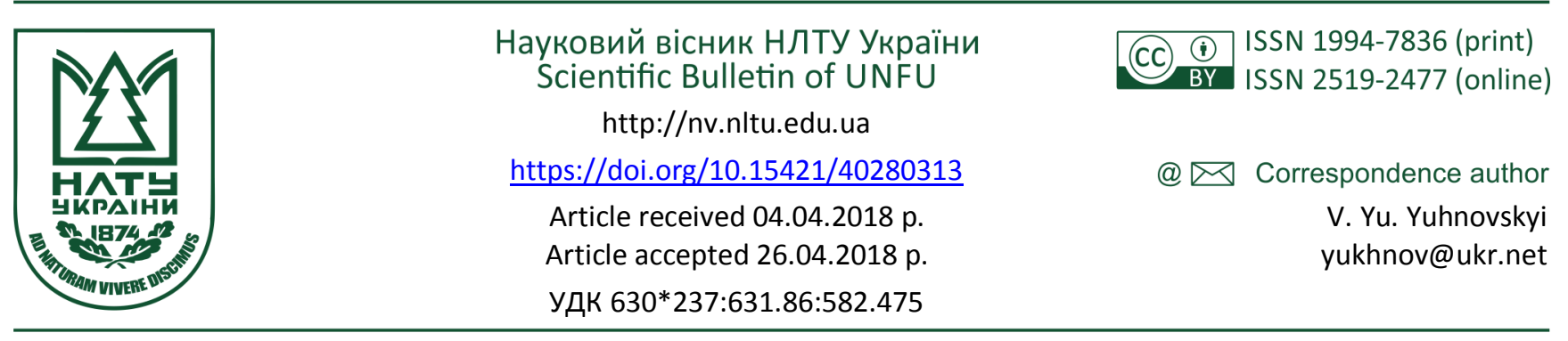

V. Yu. Yuhnovskyi', Yu. S. Urliuk ${ }^{1}$, M. P. Holovetskyi ${ }^{2}$, I. L. Sereda ${ }^{2}$

${ }^{1}$ National University of Life and Environmental Sciences of Ukraine, Kyiv, Ukraine ${ }^{2}$ SE "Vyshche-Dubecansky Forestry", State Forest Resources Agency of Ukraine, Pirnovo, Ukraine

\title{
IMPACT OF ORGANIC FERTILIZER "DOSTATOK" ON THE SURVIVAL AND GROWTH OF PINE PLANTATIONS
}

\begin{abstract}
The survival and growth of pine plantations, created at the clear cuttings, with the use of organic fertilizer "Dostatok" are analyzed. The research was conducted in 11 forest units of the State Enterprise "Vyshche-Dubechna Forestry" in the fresh poor and rich forest sites. The plantations were created according to the following schemes: 4 rows of Scotch pine and 1 row of red oak with placement of seedlings $1.5 \times 0.5 \mathrm{~m}$ and $1.5 \times 1.0 \mathrm{~m}$ by planting them in a furrow formed by a plow PKL-70. The total forest pine plantations with application of fertilizer amounted to 22.2 hectares. The agrochemical analysis revealed that $40.6 \%$ of organic matter was concentrated in the fertilizer, whereas in the organic layer of fresh poor and rich pine sites, the content of humus was $22.2 \%$ and $30.7 \%$ respectively. At the same time, fertilizer is characterized by a neutral environment, while the organic soil of fresh poor and rich pine sites has a very high acidity of the $\mathrm{pH}$ of the salt extract, which fluctuates within 3.5-3.6. The double predominance of the organic matter content in the fertilizer promotes the survival and growth of pine plantations. It was established that the introduction of fertilizer "Dostavok" in the form of tablets on the root system of pine seedlings increases the survival of forest plantations, which on sandy and sandy loam soils, respectively, reaches 90 and $95 \%$. Values of pH salt extraction indicate that the soils are very acid (3.5 and 3.1), with an average level of humus (2.4 and 7.4\%), low levels of ammonia and nitrate nitrogen and mobile phosphorus. Soil of fresh poor pine site has an elevated level of mobile potassium $\left(139.87 \mathrm{mg} \cdot \mathrm{kg}^{-1}\right)$, while the fresh rich pine site is characterized by a low level of potassium, which is $46.39 \mathrm{mg} \cdot \mathrm{kg}^{-1}$. Granulometric analysis of the soil showed that the poor sites are represented by sandy soils and rich sites - rough-dust sandy loam soils. Almost double the predominance of the organic matter content in the fertilizer "Dostatok" contributes to the survival and growth of pine plantations. The annual increment of pine seedlings on 4-7 cm was more than at the control. The use of bio-fertilizer also reduces the number of manual care and accelerates the closure in the rows, which in turn allows the transfer of forest crops to covered forest area a year earlier.
\end{abstract}

Keywords: nutrients; type of forest sites; sandy soil; seedling; root system; annual increment.

Introduction. The properties of soils of forest ecosystems after clear cuttings are still far from optimal. In most soils, there is a decrease in the content of humus, a negative balance of nitrogen, phosphorus, potassium, microelements and, consequently a decrease in the survivability and growth of forest crops. Improvement of soil fertility prevents its depletion, bogging, contaminating with various toxic substances. Organic and mineral fertilizers play a significant role in improving the quality of soil (Hrom, 2005; Marchuk et al., 2010; Pinchuk, , \& Hengalo, 2018). Organic fertilizers contain macro- and micro-elements, various physiologically active substances useful for plants, microorganisms, antibiotics, etc. Organic fertilizers contribute to the better flow of biological processes and improve the physical and chemical properties of the soil. Under proper use, organic fertilizers are a powerful reserve for increasing of soil fertility. The introduction of organic fertilizers on depleted nutrients in sandy and sandy loam soils increases the survival of forest plantations and soil fertility, accelerates the transfer of forest plantations to forest-covered areas.
Analysis of recent researches and publications. Nutrient fertilizer is the main element of the food contained in it. There are simple ones that contain one element of nutrition (nitrogen, phosphorus, potassium - macro elements; boron, manganese, molybdenum - micro elements), and complex mineral fertilizers containing two or more elements of nutrition (Marchuk et al., 2010).

The ratio of the amount of nutrient fertilizer taken away by a harvest, to the total amount of nutrient introduced with fertilizer, is characterized by the fertilizer use coefficient. On average, for all tree plants, the fertilizer use coefficient is for: nitrogen $-40-50 \%$, phosphorous $-10-25 \%$, potash $-50-60 \%$. An indicator of the quality of fertilizer is the content of nutrients in a form suitable for the assimilation of plants. To characterize the fertilizers, the mass fraction of nitrogen, phosphorus and potassium is determined in them in terms of $\mathrm{N}, \mathrm{P}_{2} \mathrm{O}_{5}, \mathrm{~K}_{2} \mathrm{O}$.

For the efficient and rational use of fertilizers in forestry production, the choice of methods for fertilizing the soil in accordance with the biological characteristics of plants is of

\section{Інформація про авторів:}

Юхновський Василь Юрійович, д-р с.-г. наук, професор. Email: yukhnov@ukr.net; yukhnov@nubip.edu.ua

Урлюк Юрій Станіславович, здобувач. Email: yuriurluk@ukr.net

Головецький Михайло Петрович, канд. с.-г. наук, директор. Email: Dybechnja@ukr.net

Середа Іван Леонідович, інженер з лісовідновлення. Email: vanyasereda1985@ukr.net

Цитування за ДСту: Юхновський В. Ю., Урлюк Ю. С., Головецький М. П., Середа I. Л. Impact of Organic Fertilizer "Dostatok" on the Survival and Growth of Pine Plantations. Науковий вісник НлтУ України. 2018, т. 28, № 3. С. 62-66.

Citation APA: Yuhnovskyi, V. Yu., Urliuk, Yu. S., Holovetskyi, M. P., \& Sereda, I. L. (2018). Impact of Organic Fertilizer "Dostatok" on the Survival and Growth of Pine Plantations. Scientific Bulletin of UNFU, 28(3), 62-66. https://doi.org/10.15421/40280313 
great importance (Marchuk et al., 2010). Fertilizers are introduced into the soil in a certain amount, which is determined by the norms and dosages of introduction.

Recently, organic fertilizers are widely used in forestry practice. So, for the cultivation of the planting material of common oak with a closed root system in individual containers with agro-fibre, the humate fertilizer "Rokohumin" was tested (Danilenko et al., 2016). The effectiveness of the fertilizer depends on the method of introduction and concentration of working solutions. The use of "Rokogumin" makes it possible to get the planting material of a certain sizes, in particular large-sized, for use not only in forest-cultivated production, but also in the garden-park industry.

Organic fertilizers contain the most important nutrients mainly in organic form and a large number of microorganisms. These include manure, peat, bird droppings (guano), various composts, organic waste from the urban economy (sewage, sewage sludge, and urban debris), sapropel, and green fertilizer. The effect of organic fertilizers on the crop yields is evident for 3-4 years or more (Marchuk et al., 2010; Sherstobaeva, 2003).

The purpose of the research is to assess the impact of the organic fertilizer "Dostatok" on the survival and growth of pine plantations in fresh pine sites and to make recommendations for the use of organic fertilizer for the creation of Scotch pine plantations on the soils of light mechanical composition.

Materials and methods of research. The research was done at the Vyshcha-Dubechna forestry enterprise. The experimental objects are located in the forest areas of the enterprise, the territory of which belongs to the Eastern-Polissya district of the forestry area and is located in a triangle, which forms the Kiev reservoir and the river Desna until it drops on the river Dnieper (Pasternak et al., 1980; Forestry, 2018; Yukhnovskyi, Urluk \& Golovetsky, 2015).

The research was conducted during 2013-2017. The effectiveness of the organic fertilizer "Dostatok" of the formation of annual growth and survivability of pine seedlings was researched at the experiment.

At the experimental plots, the pills were inserted into the sword done by Kolesova slit on the upper part of the root system of seedlings. This pursued two interrelated goals - the accumulation, retention and gradual penetration of moisture down the root system for a long period with the simultaneous increase of soil fertility in the horizon of the root system development.

Experiments were carried out in 11 forest districts of the State Enterprise "Vyshcha-Dubechna Forestry" in pine sites. The plantations were created according to the following schemes: 4 rows of Scotch pine and 1 row of red oak with placement of seedlings in $1.5 \times 0.5 \mathrm{~m}$ and $1.5 \times 1.0 \mathrm{~m}$ by planting them in a furrows formed by a Forest Plow-Cultivator (FPK-70). Forest plantations with the use of fertilizers were planted at the 22.2 hectares.

Tablets "Dostatok" is a natural ecologically pure fertilizer with moisture-retaining properties on the basis of biohumus. Fertilizer contains agronomical useful microflora of natural origin. Usually the pills based on bio-humus "Dostatok" are intended for growing seedlings, and with addition of water are increased by 3.5 times and become an excellent loose foundation for germination of seeds and the formation of a powerful root system. The tablets provide the plant with all the necessary nutrients and develop in it the resistance to diseases. For industrial purposes the tablets are available in a size of $16 \mathrm{~mm}$ in height and $30 \mathrm{~mm}$ in diameter. Unfortunately, in the instructions for the use of fertilizers, it does not indicate its acidity, the content of organic and mineral substances. It is only indicated that $50 \%$ of the tablets "Dostatok" consist of organic ingredients and, unlike the Jiffy peat tablets, do not have a grid that holds peat.

Therefore, to determine the content of organic matter and the components of $\mathrm{N}, \mathrm{P}, \mathrm{K}$ and $\mathrm{pH}$ extract salt the samples of the fertilizer were tested in the certified Ukrainian Laboratory of Quality and Safety of Agricultural Products at the National University of Life and Environmental Sciences of Ukraine (test report No. 1240 dated 09.15.2017).

To determine the impact of fertilizer on the effectiveness of pine plantations, the samples of soil of the upper 10$\mathrm{cm}$ horizon and the place of transition of litter to the soil in the fresh pine sites were chosen (protocols of tests No. $1725-\mathrm{N}, 1729-\mathrm{N}, 1727-\mathrm{N}$ and $1733-\mathrm{N}$ dated on November 20, 2017).

Determination of $\mathrm{pH}$ extract salt was carried out according to State Standard 27979-88 "Organic fertilizers. Method for determination of $\mathrm{pH}$ (Organic fertilizers: $\mathrm{pH}$ determination method) (State Standard 27979-88, 2006; State Standard 7949, 2015). Organic matter was determined according to State Standard 27980-88 "Organic fertilizers. Methods for determining the organic matter (Organic fertilizers, methods for the determination of organic matter) (State Standard 27980-88, 2006; State Standard 4289, 2004).

The total mass fraction of nitrogen was determined according to State Standard 7911:2015 "Organic and organicmineral fertilizers. Method for determination the total mass fraction of nitrogen and mass fraction of ammoniac nitrogen" (State Standard 4729, 2007; State Standard 7911, 2015). Total phosphorus on the initial moisture was determined according to State Standard 26717-85 "Organic fertilizers. Methods for determination of total phosphorus (Organic fertilizers, methods for determination of total phosphorus)" (State Standard 26717-85, 2006; State Standard 4405, 2005). The mass fraction of total potassium was determined according to State Standard 7949:2015 "Organic fertilizers. Method for determination the mass fraction of total potassium" (State Standard 7949, 2015).

Results of the research and their discussion. Analysis of the quality of the organic layer of soil, which is the lower part of the forest litter at the stage of full mineralization, has been carried out to determine the effect of fertilizer on the growth of pine plantations on the soils of different mechanical composition. Samples of this layer were taken on sandy $\left(A_{2}\right)$ and sandy loam $\left(B_{2}\right)$ soils at depths of 1-2 and $1-3 \mathrm{~cm}$, respectively. The comparative characteristic of the indicators of the quality of the organic layer of soil and the applied organic mineral fertilizer "Dostatok" is shown in the Table 1.

Data of the table 1 indicates that $40.6 \%$ of organic matter is concentrated in the fertilizer, whereas in the organic layer of fresh poor and rich pine sites the content of humus is $22.2 \%$ and $30.7 \%$ respectively. At the same time, fertilizer is characterized by a neutral reaction and the organic soil of fresh poor and rich sites has a very high acid $\mathrm{pH}$ of the salt extract, which varies within 3.5-3.6. Almost double the predominance of the organic matter content in the fertilizer "Dostatok" contributes to the survival and growth of pine plantations. 
Table 1. Indicators of quality of organic layer of soil and fertilizer

\begin{tabular}{|l|c|c|c|}
\hline \multirow{2}{*}{$\begin{array}{c}\text { Name of indicators, } \\
\text { units of measures }\end{array}$} & \multicolumn{2}{|c|}{$\begin{array}{c}\text { Type of forest } \\
\text { sites }\end{array}$} & \multirow{2}{*}{$\begin{array}{c}\text { Fertilizer } \\
\text { "Dosta- } \\
\text { tok" }\end{array}$} \\
\cline { 2 - 3 } & $\begin{array}{c}\text { poor } \\
\left(\mathrm{A}_{2}\right)\end{array}$ & $\begin{array}{c}\text { rich } \\
\left(\mathrm{B}_{2}\right)\end{array}$ & \\
\hline pH extract salt, units pH & $3.5^{ \pm 0.30}$ & $3.6^{ \pm 0.30}$ & $5.4^{ \pm 0.30}$ \\
\hline Organic matter (humus), \% & $22.2^{ \pm 1.20}$ & $30.7^{ \pm 1.20}$ & $40.6^{ \pm 1.50}$ \\
\hline $\begin{array}{l}\text { Total mass fraction of nitrogen, \% } \\
\text { of initial moisture }\end{array}$ & $0.39^{ \pm 0.10}$ & $0.54^{ \pm 0.10}$ & $0.36^{ \pm 0.10}$ \\
\hline $\begin{array}{l}\text { Mass fraction of ammonium nitro- } \\
\text { gen, \% on the initial moisture }\end{array}$ & $0.05^{ \pm 0.001}$ & $0.15^{ \pm 0.05}$ & $0.3^{ \pm 0.05}$ \\
\hline $\begin{array}{l}\text { Total phosphorus, \% on the initial } \\
\text { moisture }\end{array}$ & $0.01^{ \pm 0.005}$ & $0.08^{ \pm 0.01}$ & $0.2^{ \pm 0.05}$ \\
\hline
\end{tabular}

An important factor in the survival and growth of seedlings is the content of nutrients in the active layer of soil. For this purpose, the quality indices of a $10-\mathrm{cm}$ layer of soil were analyzed, which is shown in Table 2.

According to the results of the analysis of $10-\mathrm{cm}$ soil layer, soil grouping was carried out on the fertility indices. Values of $\mathrm{pH}$ salt extraction indicate that the soils are very acid (3.5 and 3.1), with an average level of humus (2.4 and $7.4 \%$ ), low levels of ammonia and nitrate nitrogen and mobile phosphorus. Soil of fresh poor pine sites has an elevated level of mobile potassium (139.87 $\left.\mathrm{mg} \mathrm{kg}^{-1}\right)$, while the fresh rich pine sites soil is characterized by a low level of potassium, which is $46.39 \mathrm{mg} \mathrm{kg}^{-1}$. Granulometric analysis of the soil showed that the poor sites are represented by sandy soils and rich sites - rough-dust sandy loam soils (State Standard 4730, 2007; ISO 10390, 2007).
Table 2. Indicators of soil quality of experimental pine plantations

\begin{tabular}{|c|c|c|c|c|}
\hline \multirow{4}{*}{$\begin{array}{l}\text { Name of indicators, } \\
\text { units of measures }\end{array}$} & \multicolumn{4}{|c|}{ Type of forest sites } \\
\hline & \multicolumn{2}{|c|}{$\begin{array}{l}\text { fresh poor pine } \\
\text { stand }\left(\mathrm{A}_{2}\right)\end{array}$} & \multicolumn{2}{|c|}{$\begin{array}{l}\text { fresh rich pine } \\
\text { stand }\left(B_{2}\right)\end{array}$} \\
\hline & \multicolumn{4}{|c|}{ Depth of sample taking, $\mathrm{cm}$} \\
\hline & $1-2$ & $3-10$ & $1-3$ & $4-10$ \\
\hline $\begin{array}{l}\text { pH extract salt, units } \\
\text { pH }\end{array}$ & $3.3^{ \pm 0.15}$ & $3.5^{ \pm 0.15}$ & $3.2^{ \pm 0.15}$ & $3.1^{ \pm 0.15}$ \\
\hline $\begin{array}{l}\text { Organic matter (hu- } \\
\text { mus), } \%\end{array}$ & $20.3^{ \pm 4.06}$ & $2.4^{ \pm 0.48}$ & $31.5^{ \pm 6.31}$ & $7.4^{ \pm 0.74}$ \\
\hline $\begin{array}{l}\text { Ammonia nitrogen, } \\
\mathrm{mg} \cdot \mathrm{Kg}^{-1}\end{array}$ & $45.4^{ \pm 9.08}$ & $9.2^{ \pm 1.83}$ & $4.2^{ \pm 0.63}$ & $13.2^{ \pm 2.64}$ \\
\hline $\begin{array}{l}\text { Nitrate nitrogen, } \\
\mathrm{mg} \cdot \mathrm{Kg}^{-1}\end{array}$ & $0.4^{ \pm 0.05}$ & $0.2^{ \pm 0.04}$ & $63.3^{ \pm 12.62}$ & $0.9^{ \pm 0.13}$ \\
\hline $\begin{array}{l}\text { Mobile phosphorus, } \\
\mathrm{mg} \cdot \mathrm{Kg}^{-1}\end{array}$ & $26.6^{ \pm 3.99}$ & $17.0^{ \pm 2.56}$ & $36.1^{ \pm 5.42}$ & $17.7^{ \pm 2.66}$ \\
\hline $\begin{array}{l}\text { Nobile potassium, } \\
\mathrm{mg} \cdot \mathrm{Kg}^{-1}\end{array}$ & $99.4^{ \pm 0.87}$ & $139.7^{ \pm 1.8}$ & $161.85^{ \pm 11 .}$ & $46.39^{ \pm 0 .}$ \\
\hline Type of soil & \multicolumn{2}{|c|}{ sandy } & \multicolumn{2}{|c|}{$\begin{array}{l}\text { rough-dust sandy } \\
\text { loam }\end{array}$} \\
\hline Sand $1-0,05 \mathrm{~mm}, \%$ & & 66.45 & & 63.79 \\
\hline $\begin{array}{l}\text { Rough dust } 0,05- \\
0,01 \mathrm{~mm}, \%\end{array}$ & & 25.13 & & 26.37 \\
\hline $\begin{array}{l}\text { Dust } 0,01- \\
0,001 \mathrm{~mm}, \%\end{array}$ & & 7.37 & & 8.26 \\
\hline Silt $<0,001 \mathrm{~mm}, \%$ & & 1.08 & & 1.56 \\
\hline $\begin{array}{l}\text { Physical clay } \\
<0,01 \mathrm{~mm}, \%\end{array}$ & & 9.87 & & 11.20 \\
\hline
\end{tabular}

The observation of experimental forest plantations was done by commissions consisting of a forestry engineer, a forester, a forestry assistant during September-October 2016-2017, as noted in the relevant forest survey documents. These researches are shown in Table 3.

Table 3. Survival and annual increment of pine plantation with the use of fertilizer and without fertilizer use

\begin{tabular}{|c|c|c|c|c|c|c|c|}
\hline \multirow[b]{2}{*}{ Forest farm } & \multirow[b]{2}{*}{ Block } & \multirow{2}{*}{$\begin{array}{c}\text { Type of forest } \\
\text { site* }\end{array}$} & \multirow[b]{2}{*}{ Area, ha } & \multicolumn{2}{|c|}{ Survival, \% } & \multicolumn{2}{|c|}{ Annual increment, cm } \\
\hline & & & & using fertilizer & $\begin{array}{c}\text { without } \\
\text { fertilizer use }\end{array}$ & using fertilizer & $\begin{array}{c}\text { without } \\
\text { fertilizer use }\end{array}$ \\
\hline \multirow{2}{*}{ Gutiv } & $61 / 26$ & $\mathrm{~B}_{2}$ & 2.0 & & & & \\
\hline & $62 / 12$ & $\mathrm{~B}_{2}$ & 1.0 & & & & \\
\hline \multicolumn{3}{|c|}{ Total: } & 3.0 & 91 & 84 & $12^{ \pm 1.9}$ & $7^{ \pm 0.9}$ \\
\hline \multirow{2}{*}{ Desna } & $320 / 13$ & $\mathrm{~B}_{2}$ & 1.0 & & & & \\
\hline & $332 / 27$ & $\mathrm{~B}_{2}$ & 0.4 & & & & \\
\hline \multicolumn{3}{|c|}{ Total: } & 1.4 & 90 & 84 & $10^{ \pm 1.1}$ & $6^{ \pm 0.8}$ \\
\hline \multirow{3}{*}{ Dovrobrodovsk } & $138 / 9$ & $\mathrm{~B}_{2}$ & 0.6 & & & & \\
\hline & $140 / 14$ & $\mathrm{~B}_{2}$ & 0.9 & & & & \\
\hline & $135 / 25$ & $\mathrm{C}_{3}$ & 1.4 & & & & \\
\hline \multicolumn{3}{|c|}{ Total: } & 2.9 & 90 & 85 & $10^{ \pm 0.9}$ & $6^{ \pm 0} .8$ \\
\hline \multirow{2}{*}{ Dubechna } & $687 / 5$ & $\mathrm{~A}_{2}$ & 0.5 & & & & \\
\hline & $713 / 4$ & $\mathrm{~B}_{2}$ & 1.3 & & & & \\
\hline \multicolumn{3}{|c|}{ Total: } & 1.8 & 90 & 85 & $15^{ \pm 2.3}$ & $8^{ \pm 1.2}$ \\
\hline \multirow{3}{*}{ Novosilky } & $792 / 11$ & $\mathrm{~A}_{2}$ & 0.4 & & & & \\
\hline & $793 / 9$ & $\mathrm{~A}_{2}$ & 0.3 & & & & \\
\hline & $795 / 26$ & $\mathrm{~A}_{2}$ & 0.3 & & & & \\
\hline \multicolumn{3}{|c|}{ Total: } & 1.0 & 89 & 86 & $10^{ \pm 1.5}$ & $7^{ \pm 1.0}$ \\
\hline \multirow{2}{*}{ Pirnovo } & $540 / 6$ & $\mathrm{~A}_{2}$ & 2.3 & & & & \\
\hline & $488 / 7$ & $\mathrm{~A}_{2}$ & 1.7 & & & & \\
\hline \multicolumn{3}{|c|}{ Total: } & 4.0 & 89 & 85 & $10^{ \pm 1.7}$ & $6^{ \pm 0.9}$ \\
\hline Prymorsk & $347 / 4$ & $\mathrm{~A}_{2}$ & 1.1 & 90 & 83 & $12^{ \pm 1,8}$ & $6^{ \pm 0,8}$ \\
\hline \multirow{3}{*}{ Khotianivka } & $821 / 14$ & $\mathrm{~A}_{2}$ & 0.7 & & & & \\
\hline & $825 / 17$ & $\mathrm{~B}_{2}$ & 0.4 & & & & \\
\hline & $856 / 10$ & $\mathrm{~A}_{2}$ & 2.4 & & & & \\
\hline \multicolumn{3}{|c|}{ Total: } & 3.5 & 90 & 86 & $13^{ \pm 1.8}$ & $8^{ \pm 1.0}$ \\
\hline \multirow{3}{*}{ Khutir } & $179 / 1$ & $\mathrm{~A}_{2}$ & 0.8 & & & & \\
\hline & $187 / 9$ & $\mathrm{~B}_{2}$ & 0.2 & & & & \\
\hline & $182 / 3$ & $\mathrm{~B}_{2}$ & 1.5 & & & & \\
\hline \multicolumn{3}{|c|}{ Total: } & 2.5 & 92 & 84 & $14^{ \pm 2.1}$ & $8^{ \pm 1.1}$ \\
\hline Tsenter & $274 / 16$ & $\mathrm{~A}_{2}$ & 1.0 & 88 & 84 & $12^{ \pm 1,9}$ & $7^{ \pm 0,8}$ \\
\hline \multicolumn{3}{|c|}{ Total } & 22.2 & & & & \\
\hline
\end{tabular}

* Note: $\mathrm{A}_{2}$ - fresh poor pine site; $\mathrm{B}_{2}-$ fresh rich pine site; $\mathrm{C}_{3}$ - moisture pine-oak site. 
Data of Table 3 indicates that the survival of experimental forest plantations with the use of fertilizer is varied within the range of $88-92 \%$, whereas in the control plantings this index is $83-86 \%$. At the same time, the annual increment of experimental plantations is recorded in the range of $10-15 \mathrm{~cm}$, and in the control $-6-8 \mathrm{~cm}$. The significant difference between the indices of survival and growth of pine seedlings was not detected.

Advantages of using tablets "Dostatok" are manifested in: high survival of forest plantations, accelerating the growth and development of Scotch pine plants, providing moisture to seedlings during the arid period.

Conclusions and perspectives. The results of researches testify to high efficiency of use of fertilizer "Dostatok" for creation of high productive forest plantations. The agrochemical analysis revealed that $40.6 \%$ of organic matter was concentrated in the fertilizer, whereas in the organic layer of fresh poor pine and fresh rich pine sites the content of humus was $22.2 \%$ and $30.7 \%$ respectively. At the same time, fertilizers are characterized by a neutral reaction while the organic soil of fresh poor and rich pine sites have very high acidity of the $\mathrm{pH}$ of the salt extract, which fluctuates within 3.5-3.6.

The introduction on the root system of pine seedlings increases the survival of forest crops on sandy and sandy soils, which is 88 and $92 \%$ respectively. The annual height increment of pine seedlings exceeded the control values by 4-7 cm.

The use of bio-fertilizer also reduces the amount of manual care and accelerates the closure in the rows, which in turn enables the transfer of forest crops to the forest-covered vegetation of the land a year earlier. It argues the perspective of use the fertilizer on sandy and sandy loam soils in the poor and rich fresh pine sites in the region.

\section{Перелік використаних джерел}

Danilenko, O. M., Tarnopilsky, P. B., Gladun, G. B., Gupal, V. V., Volkov, P. O., Kosatiy, D. M., \& Samoilov, P. V. (2016). Use of "Roko-humin" for growing oak seedlings. Arboriculture and agroforestry, 129, 93-99. [In Ukrainian].

Forestry. (2018). The project of the organization and development of forestry of the State Enterprise "Vyshche-Dubechna Forestry". Irpin. Ukrlisproek. Vol. 1, Book. 1. 210 p.
Hrom, M. M. (2005). Simulation of the growth of forest crops of juvenile age by the introduction of mineral fertilizers in the West Forest-steppe. Scientific Bulletin of UNFU, 15(1), 29-34. [In Ukrainian].

ISO 10390:2007. Quality of soil. Determination of pH. [In Ukrainian]. Marchuk, I. U., Makarenko, V. M., Rostalnoi, V. Ye., Savchuk, A. V., \& Filonov, E. A. (2010). Fertilizers and their use. Kyiv: Aristee. 253 p. [In Ukrainian].

Pasternak, P. S., Kiselevsky, R. G., Fedets, I. F., \& Medvedev, L. A. (1980). Forestry zoning of the Ukrainian SSR. Forestry and agroforestry, 56, 3-16. [In Russian].

Pinchuk, A. P., \& Hengalo, O. M. (2018). Efficiency of root-crops for increasing the productivity of accumulation of mass and elements of mineral nutrition by pine seedlings. Retrieved from: Ejournal.studnubip.com/zhurnal-8/ukr/. [In Ukrainian].

Sherstobaeva, E. (2003). Bio-preparations - a jump in resource-saving and ecologically safe agriculture. Agricultural machinery news, 1, 32. [In Ukrainian].

State Standard 26717-85. (2006). Organic fertilizers. Methods for determining of total phosphorus. [In Russian].

State Standard 27979-88. (2006). Organic fertilizers. Method for determination of $\mathrm{pH}$. [In Russian].

State Standard 27980-88. (2006). Organic fertilizers. Methods for determination of organic matter. [In Russian].

State Standard 4289: 2004. Quality of soil. Methods of determination of organic matter. [In Ukrainian].

State Standard 4405:2005. Quality of soil. Determination of mobile compounds of phosphorus and potassium by methods of Kirsanov in the modification of the Soil Research Institute named after O. N. Sokolovsky. [In Ukrainian].

State Standard 4729:2007. Quality of soil. Determination of nitrate and ammonium nitrogen in the modification of the Soil Research Institute named after O. N. Sokolovsky. [In Ukrainian].

State Standard 4730:2007. Quality of soil. Determination of granulometric composition by the pipette method in the modification of N. A. Kachynskyi. [In Ukrainian].

State Standard 7911:2015. Organic and organic-mineral fertilizers. Method of determining the total mass fraction of nitrogen and the mass fraction of ammonia nitrogen. [In Ukrainian].

State Standard 7949: 2015. Organic fertilizers. Method of determining the mass fraction of total potassium. [In Ukrainian].

Yukhnovskyi, V. Yu., Urluk, Yu. S., \& Golovetsky, M. P. (2015). Dynamics of the forest fund of the State Enterprise "VyscheDubecansky Forestry". Scientific Bulletin of UNFU, 25(8), 8-15. [In Ukrainian].

\author{
В. Ю. Юхновський', Ю. С. Урлюк', М. П. Головецький', І. Л. Середа \\ ${ }^{1}$ Наиіональний університет біоресурсів і природокористування Украӥни, м. Київ, Україна \\ 2 ДП "Вище-Дубечанське лісове господарство" Держслісагентства України, с. Пірново, Україна
}

\title{
ВПЛИВ ОРГАНІЧНОГО ДОБРИВА "ДОСТАТОК" НА ПРИЖИВЛЮВАНІСТЬ I РІСТ СОСНОВИХ КУЛЬТУР
}

\begin{abstract}
Проаналізовано приживлюваність і ріст соснових культур, створених на зрубах, з використанням органічного добрива "Достаток". Дослідження проведено в 11 лісництвах ДП "Вище-Дубечанське лісове господарство" в борових і суборових типах лісорослинних умов. Культури створено за схемами: 4pСз1рДчр, з розміщенням сіянців 1,5×0,5 м та 1,5×1,0 м висаджуванням їх у борозни, утвореними плугом ПКЛ-70. Загальна площа створених лісових культур із застосуванням добрива становила 22,2 га. За результатами агрохімічного аналізу встановлено, що у добриві сконцентровано 40,6 \% органічної речовини, тоді як в органічному шарі грунту свіжого бору і субору вміст гумусу становить 22,2 і 30,7 \% відповідно. Водночас добриво характеризується нейтральним середовищем, а органічний грунт свіжого бору і субору має дуже сильнокислий показник $\mathrm{pH}$ сольової витяжки, який змінюється в межах 3,5-3,6. Подвійне переважання вмісту органічної речовини у добриві "Достаток" сприяє приживлюваності і росту соснових культур. Встановлено, що внесення добрива "Достаток" у вигляді таблеток на кореневу систему сіянців сосни підвищує приживлюваність лісових культур, яка на піщаних і супіщаних грунтах відповідно сягає 88 і 92 \%. Річний приріст сіянців сосни звичайної на 4-7 см перевищував контрольні показники. Використання біопрепарату також зменшує кількість ручних доглядів і пришвидшує змикання в рядах, що дає змогу перевести лісові культури в покриту лісовою рослинністю площу на рік раніше.
\end{abstract}

Ключові слова: елементи живлення; тип лісорослинних умов; піщаний грунт; сіянець; коренева система; річний приріст. 
В. Ю. Юхновский'

${ }^{1}$ Национальный университет биоресурсов и природопользования Украины, г. Киев, Украина

${ }^{2}$ ГП "Выше-Дубечанское лесное хозяйство" Гослесагентства Украины, с. Пирново, Украина

\section{ВЛИЯНИЕ ОРГАНИЧЕСКОГО УДОБРЕНИЯ "ДОСТАТОК"} НА ПРИЖИВАЕМОСТЬ И РОСТ СОСНОВЫХ КУЛЬТУР

Проанализированы приживаемость и рост сосновых культур, созданных на вырубках, с использованием органического удобрения "Достаток". Исследование проведено в 11 лесничествах ГП "Выше-Дубечанское лесное хозяйство" в боровых и суборевых типах лесорастительных условий. Культуры созданы по схемам: $4 \mathrm{pC} 1 \mathrm{pД \kappa р,} \mathrm{с} \mathrm{размещением} \mathrm{сеянцев} \mathrm{1,5×0,5} \mathrm{м} \mathrm{и}$ $1,5 \times 1,0$ м и высадкой их в борозды, образованными плугом ПКЛ-70. Общая площадь созданных лесных культур с применением удобрения составила 22,2 га. По результатам агрохимичесого анализа установлено, что в удобрении сконцентрировано $40,6 \%$ органического вещества, тогда как в органическом слое почвы свежего бора и субора содержание гумуса составляет 22,2 и $30,7 \%$ соответственно. Удобрение характеризуется нейтральной средой, тогда как органический слой почвы свежего бора и субора имеет очень сильнокислый показатель $\mathrm{pH}$ солевой вытяжки, который колеблется в пределах $3,5-3,6$. Почти двойное преобладание содержания органического вещества в удобрении "Достаток" способствует приживаемости и росту сосновых культур. Установлено, что внесение удобрения "Достаток" в виде таблеток на корневую систему сеянцев сосны повышает приживаемость лесных культур, которая на песчаных и супесчаных почвах соответственно составляет 90 и $95 \%$. Годовой прирост сеянцев сосны обыкновенной на 4-7 см превышал контрольные показатели. Использование биопрепарата также уменьшает количество ручных уходов и ускоряет смыкания в рядах, что дает возможность перевести лесные культуры в покрытую лесом площадь годом ранее.

Ключевые слова: элементы питания; тип лесорастительных условий; песчаная почва; сеянец; корневая система; годичный

прирост. 